\title{
Dakwah Berbasis Pemberdayaan Ekonomi dan Peningkatan Kesejahteraan Mad'u
}

\author{
Asep Iwan Setiawan \\ UIN Sunan Gunung Djati Bandung \\ E-mail: iwanfidkombdg@gmail.com
}

\begin{abstract}
Dompet Peduli Umat (DPU) Daarut Tauhid exists around people through Desa Ternak Mandiri (DTM) program as a concern in poverty. DTM program conducted by the DPU has a unique character which using this approach in doing poverty alleviation mission. This phenomena indicates that the DPU has contributed to the community to improve the welfare of people who are categorized as a poor. With typical propaganda materials that can motivate and help people who are economically weak to grow and be empowered so they can live independent economically and spiritually as well. This program succeed to increase such as family income, a better understanding of the religious, and scientific livestock management. These sciences and experiences are very useful to them to support life after the program is completed. This program is run by zakat funds raised by the charity as well as active participation DPU's companion activities that comprise the religious field assistance, animal healthcare assistance deployed at the Desa Ternak Mandiri at Cimenyan Bandung.
\end{abstract}

\author{
Kata Kunci: \\ Dakwah, Pemberdayaan Ekonomi Umat, Kesejahteraan, \\ Desa Ternak Mandiri
}

\section{A. Pendahuluan}

Gerakan dakwah yang dilakukan oleh para da'i pada saat ini secara kuantitas mengalami peningkatan. Secara kasat mata dapat dilihat bahwa para da'i melakukan dakwahnya dengan berbagai media 
seperti televisi, radio, koran, majalah, telepon genggam dan internet. Dengan penggunaan media yang semakin banyak, dakwah yang dilakukan para da'i telah menambah keilmuan agama dari para mad'u serta berimplikasi positif pada peningkatan pemahaman keagamaan yang semakin komprehensif. Hal ini tentunya diharapkan dapat berbanding lurus dengan peningkatan produktivitas umat. Untuk mewujudkan itu perlu ada langkah dakwah lanjutan yang memotivasi dan mengembangkan mad'u pada tingkat yang lebih mapan baik dari segi keilmuan agama maupun sektor ekonominya. Sehingga melahirkan keseimbangan dalam memenuhi kebutuhan rohani dan jasmani.

Oleh karena itu gerakan dakwah dengan model pemberdayaan ekonomi merupakan salah satu terobosan, agar umat tidak hanya "kenyang" oleh makanan rohani saja tapi juga secara jasmani. Hal ini merupakan upaya para da'i untuk meningkatkan kesejahteraan umat dengan program ekonomi yang berbasis Islam. Dengan demikian, tampak jelas bahwa dakwah dalam bidang ekonomi merupakan suatu keniscayaan pada era ini. Sehingga setiap mad'u dapat menjadi berdaya, dengan tujuan akhir menjadi masyarakat yang sejahtera.

Untuk memenuhi tuntutan di atas, Dompet Peduli Ummat (DPU) Daarut Tauhiid Bandung melalui kegiatan Misykat (Microfinance berbasis masyarakat) mempraktikan model dakwah berbasis pemberdayaan masyarakat yang khas dengan karakter DPU Daarut Tauhiid Bandung. Model dakwah ini merupakan adopsi dari program Grameen Bank Muhammad Yunus yang telah disesuaikan dengan kondisi Indonesia oleh Iwan Rudi Saktiawan, M.Ag., sebagai pelopor Misykat pada lembaga amil zakat DPU Daarut Tauhiid Bandung. Program ini telah memberikan wajah baru dalam dunia dakwah Islam.

Adapun pola yang dilakukan DPU adalah dengan memberikan bantuan dana yang berasal dari zakat untuk dijadikan modal usaha dan tentunya dengan pola pendampingan yang memiliki kurikulum dan silabus dakwah dari materi yang telah ditetapkan di DPU Daarut Tauhiid Bandung.

Penelitian ini dilakukan dalam rangka melakukan penelaahan terhadap model dakwah berbasis pemberdayaan yang dilakukan pada Dompet Peduli Umat Daarut Tauhiid Bandung sebagai lembaga amil zakat nasional yang telah memiliki kualifikasi baik. Penelaahan ini 
Asep Iwan Setiawan: Dakwah Berbasis Pemberdayaan Ekonomi...

terutama meliputi bagaimana DPU Daarut Tauhiid dapat mengembangkan dan melakukan model dakwah berbasis pemberdayaan.

\section{B. Kajian Teori}

Secara konseptual pemberdayaan atau pemberkuasaan (empowerment) berasal dari kata power (kekuasaan atau keberdayaan). Konsep mengenai kekuasaan merupakan ide utama dalam hal pemberdayaan. Kekuasaan sendiri selalu diartikan sebagai kemampuan untuk mengatur orang lain sesuai dengan yang kita inginkan. Pemberdayaan berdasarkan perspektif sosiologi adalah menampilkan peran-peran aktif dan kolaboratif antara masyarakat dan mitranya. Adanya kerja sama yang saling berkesinambungan dan melaksanakan tugasnya masing-masing.

Definisi pemberdayaan dilihat dari tujuan, proses dan cara-cara pemberdayaan:

1) Pemberdayaan bertujuan untuk meningkatkan kekuasaan orang-orang yang lemah atau tidak beruntung,

2) Pemberdayaan adalah sebuah proses dengan mana orang menjadi cukup kuat untuk berpartisipasi dalam berbagai pengontrolan atas dan mempengaruhi terhadap kejadiankejadian serta lembaga-lembaga yang dipengaruhi kehidupannya. Pemberdayaan menekankan bahwa orang memperoleh keterampilan, pengetahuan dan kekuasaan yang cukup untuk mempengaruhi kehidupannya dan kehidupan orang lain yang menjadi perhatiannya,

3) Pemberdayaan merujuk pada usaha pengalokasian kembali kekuasaan melalui pengubahan struktur sosial,

4) Pemberdayaan adalah suatu cara dengan mana rakyat, organisasi dan komunitas diarahkan agar mampu menguasai (atau berkuasa atas) kehidupannya.

Pemberdayaan masyarakat adalah sebuah konsep pembangunan ekonomi yang merangkum nilai-nilai sosial. Konsep ini mencerminkan paradigma baru pembangunan yaitu yang bersifat "people-centered, participatory, empowering, and sustainable" . 
People centered merupakan tatanan kepemerintahan yang berorientasi pada kepentingan-kepentingan masyarakat dan dalam prosesnya pun dominan dilakukan oleh masyarakat. Masyarakat diposisikan sebagai pemeran utama dalam melakukan pengambilan keputusan, pelaksanaan program dan kegiatan sekaligus pengawasan dan pertanggungjawaban secara terbuka dilakukan oleh dari dan untuk masyarakat. Konsepsi people centered ini relevan dengan ruh demokrasi yang juga mensyaratkan partisipasi masyarakat dalam mewujudkan setiap harapan dan cita-cita masyarakat itu sendiri

Pada kenyataan proses pemberdayaan masyarakat tidak hanya mengembangkan potensi ekonomi rakyat tetapi juga harkat dan martabat, rasa percaya diri dan harga dirinya, terpeliharanya tatanan nilai budaya setempat dan bahkan pada negara yang menganut theisme akan mengembalikan pada nilai-nilai ketuhanan atau dalam konsep Islam disebut sebagai nilai-nilai ilahiyah.

Secara khusus, yang menjadi tujuan utama pemberdayaan adalah memperkuat kekuasaan masyarakat, khususnya kelompok lemah yang memiliki ketidakberdayaan. Adapun pengelompokan yang dapat dikategorikan sebagai kelompok lemah atau tidak berdaya meliputi:

1) Kelompok lemah secara struktural, baik lemah secara kelas, gender maupun etnis,

2) Kelompok lemah khusus, seperti manula, anak-anak dan remaja penyandang cacat, gay dan lesbian, masyarakat terasing,

Dalam konteks dakwah, pemberdayaan disebut sebagai tamkiinu al-Dakwah yang memiliki makna kekuatan, kekuasaan, kepedulian dan kemauan yang keras. Arah pemberdayaan diharapkan tepat pada sasaran yang dimulai dari kemiskinan dan simbol-simbol ketidakberdayaan lainnya. Sasaran pemberdayaan dilihat dari segi penyandang masalah kesejahteraan sosial, yaitu:

1) Kemiskinan, yaitu penduduk Indonesia yang termasuk kategori fakir miskin,

2) Ketelantaran, yaitu kondisi tidak terpenuhinya kebutuhan dasar manusia, yang melanda anak-anak, perempuan dan lanjut usia, gelandangan dan pengemis, 
3) Kecacatan baik cacat secara fisik ataupun cacat secara mental,

4) Ketuna-sosialan, yaitu kondisi disharmonisasi dengan nilai susila dan sosial budaya yang umum berlaku di masyarakat,

5) Bencana, baik bencana alam maupun bencana sosial.

Jika kajian pemberdayaan dimulai dari kemiskinan maka ada tiga strategi utama pemberdayaan dalam praktek perubahan sosial, yaitu tradisional, direct action (aksi langsung), dan transformasi. Pertama, strategi tradisional menekankan pada kebebasan dalam memilih kepentingan dengan sebaik-baiknya dalam berbagai keadaan Kedua, direct action atau tindakan langsung, yaitu dimunculkannya dominasi kepentingan yang dihormati oleh semua pihak yang terlibat dan mempunyai peluang yang besar untuk terjadinya perubahan. Kondisi seperti ini dapat diawali oleh kebutuhan dasar kolektif (basic need collectivity) dari masyarakat seperti tuntutan reformasi supaya keluar dari krisis multidimensi. Ketiga, strategi pemberdayaan transformatif yaitu pemberdayaan yang berbasis pendidikan masyarakat secara paritisipatif yang menekankan kesadaran-kesadaran kritis untuk menjunjung nilai-nilai kebersamaan dan hubungan yang mutualistik

Terdapat tiga tingkat dalam pendekatan strategi pemberdayaan yaitu: mikro, mezzo dan makro. Dengan adanya ketiga strategi tersebut bisa dijadikan sebagai acuan dalam pemecahan masalah yang disesuaikan dengan kapasitas masyarakat.

Lebih jauh, ada tiga pendekatan strategi pemberdayaan, yaitu:

a. Aras mikro. Pemberdayaan dilakukan kepada klien secara individu melalui bimbingan, konseling, stress management, crisis intervention. Tujuan utamanya adalah membimbing atau melatih klien menjadikan tugas-tugas kehidupannya sehingga model ini sering disebut sebagai Pendekatan yang Berpusat pada Tugas (Task-Centred Approach)

b. Aras mezzo. Pemberdayaan dilakukan terhadap sekelompok klien. Pemberdayaan dilakukan dengan menggunakan kelompok sebagai media intervensi. Pendidikan dan pelatihan, dinamika kelompok, biasanya digunakan sebagai strategi dalam meningkatkan kesadaran, pengetahuan, keterampilan 
dan sikap-sikap klien agar memiliki kemampuan memecahkan permasalahan yang dihadapinya

c. Aras makro. Pendekatan ini disebut juga sebagai Strategi Sistem Besar (Large-System Strategy), karena sasaran perubahan diarahkan pada sistem lingkungan yang lebih luas, perumusan kebijakan, perencanaan sosial, kampanye, aksi sosial, lobbying, pengorganisasian masyarakat, manajemen politik, adalah beberapa strategi dalam pemberdayaan ini. Sistem strategi besar memandang klien sebagai orang yang memiliki kompetensi untuk memahami situasi-situasi mereka sendiri dan untuk memilih setra menentukan strategi yang tepat untuk bertindak.

Dari pendekatan strategi mikro, mezzo maupun makro, ketiganya dilakukan sebagai tahapan pemberdayaan dari lingkup yang kecil dan bisa dilakukan secara personal sampai pada ruang lingkup yang lebih luas sasaran dari pemberdayaan adalah seluruh masyarakat dengan memprioritaskan pemberdayaan pada masyarakat tertindas yang lemah (kaum mustadz'afiin). Korelasi yang dapat diwujudkan adalah pada syarat-syarat pemberdayaan yang mengharuskan partisipasi dan kental dengan suasana demokrasi. Pada masyarakat demokratis akan menghasilkan tekanan secara bottom-up dari kaum mustadz'afiin yang tentunya secara kuantitas lebih banyak daripada kelompok pemerintahan yang pada suasana kemiskinan dipandang kelompok orang-orang kaya yang dzalim (kaum muthrafiin).

Nilai-nilai untuk mewujudkan kesejahteraan secara dinamis dilakukan oleh para pemikir. Vic George \& Paul Wilding menyebut kelompok-kelompok yang melakukan bongkar pasang atas nilai itu dengan golongan antikolektivis,

Golongan antikolektivis adalah golongan yang menganut faham liberalisme yaitu golongan yang mengumandangkan kemerdekaan individualisme dan ketidaksamaan merupakan nilai-nilai sosial yang hakiki. Adapun golongan antikolektivis setengah hati (reluctant collectivities) adalah sama dengan golongan antikolektivis tetapi golongan ini tidak begitu mempertahankan nilai-nilai yang mutlak karena kecenderungan pada pragmatisme intelektual. Sedangkan golongan sosialis fabian adalah golongan yang percaya bahwa 
kapitalisme dapat ditransformasikan secara damai menjadi sosialisme. Dan golongan marxis adalah golongan yang menekankan pada perubahan social disandarkan pada prinsip kebebasan sipil dan persamaan di bidang ekonomi.

Dalam perspektif dakwah Islam, pemberdayaan disebut sebagai tamkiin al-Dakwah yaitu aktivitas menyeru, memotivasi, memfasilitasi, memediasi dan mengadvokasi masyarakat baik yang kaya (aghniya) ataupun yang miskin (fuqoro wa al-masakiin) untuk saling menguatkan dengan perekat nilai-nilai kejujuran, keadilan, tanggung jawab, kepedulian dan kasih sayang yang tentunya diajarkan oleh Islam sehingga tumbuh kesatuan ummat (wahdat al-ummah) dalam perbedaan status sosial dan income proverty.

Term pemberdayaan dalam al-Qur'an dan Hadits sepadan dengan makna amkaana, makkana, makiin, numkiinu, tamkiinu yang bermakna penguatan atau kekuatan (power/ empowerment). Kata tamkiin sebagai konsepsi pemberdayaan di dalam al-Qur an surat al-Anfaal ayat 71, yakni,

Artinya: "Akan tetapi jika mereka (tawanan-tawanan itu) bermaksud hendak berkhianat kepadamu, Maka Sesungguhnya mereka telah berkhianat kepada Allah sebelum ini, lalu Allah menjadikan(mu) berkuasa terhadap mereka. dan Allah Maha mengetahui lagi Maha Bijaksana"

Dalam perspektif Islam, manusia dalam kehidupannya mempunyai dua segi yang berlain-lainan: Pertama, ia tunduk kepada undang-undang fitrah dan mematuhinya karena nalurinya. Kedua, ia telah dikaruniai akal, daya untuk memahami, memperhatikan dan menentukan pendapat. Maka ia dapat menerima sesuatu dan menolak yang lain, menyukai sesuatu jalan dan membenci yang lain dan menciptakan dari dirinya sendiri sesuatu kaedah untuk berbagai-bagai segi kehidupan atau menerima suatu sistim kehidupan yang diciptakan oleh orang lain. Jadi ia tidak terikat oleh dunia ini, tetapi ia telah diberi kemerdekaan berfikir dan kemerdekaan menentukan pilihannya mengenai pendirian dan perbuatannya.

Untuk mendapatkan cita-cita luhur yang futuristik dan baik tersebut, tentunya proses menjalaninya harus dengan cara-cara yang baik dengan fondasi nilai-nilai dan prinsip yang baik. Dalam 
mengejawantahkan nilai-nilai tersebut hanya didapat dengan mencontoh keteladanan Nabi Muhammad saw sebagai representasi ajaran al-Qur an secara holistik dan universal.

Social capital dalam wacana civil society-tanpa harus mengklaim eksistensinya-serarah dengan ajaran Islam yang menjunjung tinggi ajaran kebenaran dan kebaikan seperti kejujuran, keadilan, kasih sayang, kepedulian dan lain lain sebagaimana pemberdayaan yang dibangun oleh nabi Muhammad Saw pada masyarakat Madinah yang kemudian dikonsepsi menjadi masyarakat madani.

Pemberdayaan yang dilakukan berupaya untuk menciptakan desa mandiri. Desa menurut undang-undang didefinisikan UU No. 5/1979 adalah wilayah yang ditempati oleh sejumlah penduduk sebagai persatuan masyarakat, termasuk di dalamnya kesatuan masyarakat hukum yang mempunyai organisasi pemerintahan terendah langsung di bawah camat dan berhak menyelenggarakan rumah tangganya sendiri. Sedangkan menurut UU No.22/1999, UU No.32/2004: Desa atau yang disebut dengan nama lain, selanjutnya disebut desa, adalah kesatuan masyarkaka. hukum yang memiliki kewenangan untuk mengatur dan mengurus kepentingan masyarakat setempat berdasarkan asal-usul dan adat-istiadat setempat yang diakui dalam sistem pemerintahan nasional dan berada di daerah kabupaten.

Oleh karena itu berbagai potensi yang dimiliki oleh desa merupakan modal dasar untuk dapat menjadi berkembang. Konsep Desa Mandiri merupakan konsep pembangunan yang mengandalkan potensi pemberdayaan masyarakat, dengan memberikan peluang kepada masyarakat untuk berperan dalam pengelolaan sumber daya untuk pembangunan Suatu desa dapat dikatakan mandiri jika telah memiliki prasyarat seperti, adanya sumber pendapatan desa di luar bantuan pemerintah, menyelenggarakan urusan desa secara mandiri, dan mampu membuat rancangan anggaran biaya desa.

Kesejahteraan sosial, yaitu tercukupinya kebutuhan material dan non-material. Dalam masyarakat Indonesia, kondisi sejahtera itu diartikan hidup aman dan bahagia karena semua kebutuhan dasar dapat terpenuhi, seperti makanan yg cukup, gizi, kesehatan, tempat tinggal, pendidikan, pendapatan yg layak, dan perlindungan. Dalam buku Tiga 
Orientasi Kesejahteraan Sosial, definisi kesejahteraan sosial dibedakan menjadi 3 kelompok, yaitu; kesejahteraan sebagai sebuah kegiatan atau pelayanan, keadaan dan ilmu. Yang dimaksud dengan kesejahteraan sebagai sebuah keadaan adalah kesejahteraan yang meliputi jasmaniah, rohaniah dan bukan merupakan perbaikan dan pemberantasan keburukan sosial tertentu saja.

Kesejahteraan sosial menurut Friedlander dalam Harsono (2006: 8) dinyatakan bahwa kesejahteraan sosial merupakan sistem yang terorganisasi dari pelayanan-pelayanan dan lembaga-lembaga sosial, yang dimaksudka untuk membantu individu-individu dan kelompokkelompok agar mencapai tingkat hidup dan kesehatan yang memuaskan dan hubungan-hubungan personal dan sosial yang memberi kesempatan kepada mereka untuk memperkembangkan seluruh kemampuan dan untuk meningkatkan kesejahteraan sesuai dengan kebutuhan-kebutuhan keluarga dan masyarakatnya" definisi tersebut merupakan definisi kesejahteraan sosial sebagai sebuah keadaan, yang mencerminkan bahwa manusia adalah makhluk sosial yang yang harus saling membantu agar menciptakan suasana yang harmonis dan sejahtera.

\section{Kerangka Pemikiran}

Penelitian ini berangkat dari pemikiran bahwa dakwah dalam perpektif pemberdayaan ekonomi merupakan hal yang sangat penting dan dapat menguatkan taraf kehidupan mad'u dalam bidang ekonomi. Hal ini tentunya dibarengi dengan tingkat pemahaman keagamaan mad'u yang meningkat sehingga diharapkan pengamalan agama dari mad'u semakin baik. 
Gambar 1:

Skema Kerangka Pemikiran

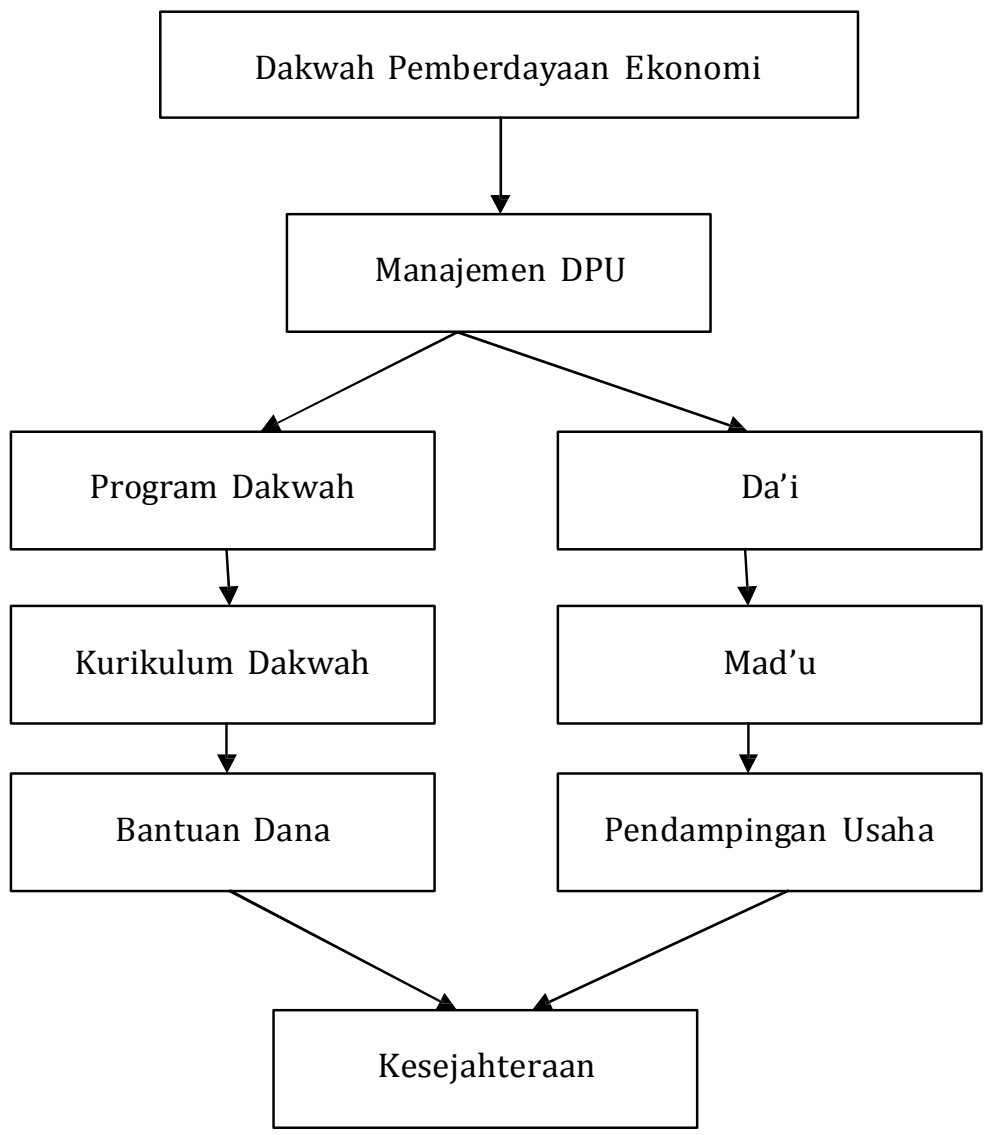

\section{Metodologi Penelitian}

Penelitian ini menggunaan metode deskriptif yang tekanannya lebih menitikberatkan pada penelusuran dan pemberian gambaran mengenai gejala-gejala yang terjadi di masyarakat yang paling aktual. Penggunaan metode ini berkaitan dengan alasan sasaran utama dari penelitian ini adalah dapat diperolehnya gambaran objektif mengenai fakta-fakta spesifik yang terkait dengan realitas latar historis dakwah berbasis pemberdayaan Dompet Peduli Ummat Daarut Tauhiid Bandung 
Pengumpulan data primer dari responden dilakukan dengan kuesioner, wawancara mendalam (in depth interview) dan observasi. Selain itu, untuk kepentingan pengumpulan data sekunder, baik teori, pandangan-pandangan, hasil penelitian, buku dan catatan-catatan, juga digunakan studi dokumentasi dan kepustakaan.

Kuesioner dilakukan untuk memperoleh informasi yang relevan dengan tujuan penelitian, dan untuk memperoleh informasi dengan validitas dan reliabilitas setinggi mungkin. Teknik wawancara, baik terstruktur maupun tidak terstruktur, dilakukan terutama untuk mengetahui pandangan, pendapat, keterangan, atau kenyataankenyataan yang dilihat dan dialami oleh responden

Observasi langsung (direct observation) dilakukan untuk memperoleh data secara langsung dari sumber primer (first hand), studi dokumentasi dan kepustakan dilakukan terutama untuk melengkapi dan menguatkan data yang diperoleh baik dari hasil kuesioner, wawancara maupun observasi.

Data yang dihasilkan kemudian diolah melalui beberapa tahapan, antara lain:

Pertama, data yang diperoleh dari hasil wawancara dan observasi yang merupakan opini, penuturan pengalaman, suasana kehidupan, dan perilaku teramati lainnya, dicatat dilakukan reduksi data, sehingga diperoleh pokok-pokok yang sistematis sesuai dengan tujuan penelitian. Kedua, data hasil wawancara dan observasi yang telah direduksi dan disusun merupakan materi untuk diinterpretasikan sesuai dengan fakta yang ada pada sampel penelitian. Ketiga, adalah memberikan makna terhadap apa yang diperoleh dari tahap interpretasi terhadap fakta hasil penelitian. Keempat, setelah catatan pada tahap ketiga tersusun secara sistematik, dilakukan pengelompokan data berdasarkan konsep, dan dicari hubungan antarkonsep yang ada, sehingga merupakan eksplanasi, baik dalam bentuk pemahaman maupun prediksi terhadap fenomena yang diteliti. 


\section{E. Hasil Penelitian dan Pembahasan}

\section{a. Kondisi Umum}

Dompet Peduli Umat adalah sebuah Lembaga Amil Zakat Nasional dan merupakan lembaga nirlaba yang bergerak di bidang penghimpunan (fundraising) dan pendayagunaan dalam zakat, infaq, shadaqah dan wakaf (ziswaf).

Latar belakang berdirinya DPU-DT adalah bahwa Indonesia sebagai negara dengan jumlah penduduk muslim terbesar di dunia memiliki potensi zakat yang amat besar. Sayangnya pada saat ini sebagian besar masyarakat masih belum memiliki kesadaran untuk berzakat sesuai dengan ketentuannya sehingga potensi besar tersebut belum sepenuhnya termaksimalkan.

Lembaga Amil Zakat DPU Daarut Tauhiid dalam kiprahnya, telah mendapatkan perhatian pemerintah, kemudian ditetapan menjadi Lembaga Amil Zakat Nasional (LAZNAS) sesuai dengan SK Menteri Agama No 410 tahun 2004 pada tanggal 13 Oktober 2004.

Program pemberdayaan kaum dhuafa melalui pemberian bantuan modal usaha, pendamping, pemasaran, pendidikan dan pelatihan keterampiln, serta pembinaan yang sistematis dan berkesinambungan sehingga mereka bisa menjalankan usahanya dengan sebaik-baiknya, dan terwujudnya kemandirian. Hingga data terakhir tahun 2012 lebih dari 10.000 orang mendapat manfaat dari program pemberdayaan ekonomi DPU-DT.

Adapun program pemberdayaan yang dikembangkan oleh DPU Daarut Tauhiid diantaranya sebagai berikut:

1. Misykat

Misykat (Microfinance Syariah Berbasis Masyarakat) merupakan perogram pemberdayaan ekonomi produktif yang dikelola secara sistematis, intensif dan berkesinambungan. Disini para peserta (mustahik) diberi dana bergulir, keterampilan dan wawasan usaha.

\section{Desa Ternak Mandiri}

Program penggemukan hewan ternak yang sasarannya adalah memberdayakan peternak kecil di pedesaan. Perogram 
dilaksanakan dalam bentuk pengelolaan hewan ternak yang berkualitas sampai pada proses pemasaran melalui program pendampingan yang intensif dan berkesinambungan.

Desa Ternak Mandiri adalah desa yang kehidupan ekonominya dan sosialnya sehat, dikelola oleh dari dan untuk warga desa sendiri. Bisa bekerjasama dengan pihak luar berdasarkan prinsip keadilan dan kemalahatan.

Adapun tujuan dari program ini antara lain:

a. Meningkatkan kesejahteraan keluarga melalui program pemberdayaan ekonomi keluarga,

b. Meningkatkan derajat kesehatan mesyarakat,

c. Meningkatkan kualitas pendidikan masyarakat melalui pendidikan formal dan informasi melalui bentuk pendmpingan dan pembinaan spiritual (caracter building),

d. Meningkatkan pengelolaan SDA pedesaan dengan asupan teknologi tepat guna dalam rangka meningkatkan daya saing hasil produksi secara luas,

e. Membantu menyediakan lapangan kerja beru bagi masyarakat pedesaan.

\section{G. Penutup}

Berdasarkan hasil penelitian yang telah dilakukan, maka dapat disimpulkan hal-hal sebagai berikut :

1. DPU-DT berusaha menyalurkan dana yang sudah diterima kepada mereka yang benar-benar berhak dengan baik dan tepat sasaran dimana yang menerima zakat benar benar masyarakat yang membutuhkannya.

2. Zakat yang disalurkan dapat digunakan dengan cara pemberdayaan bukan hanya diberikan begitu saja untuk peningkatan kekuatan ekonomi dan pembelajaran bagi masyarakat merupakan prioritas yang harus diutamakan sehingga upaya-upaya untuk menumbuhkan kemampuan dan kemandirian ummat yang berasal dari sinergi potensi masyarakat patut untuk diwujudkan secara bersama-sama. 
3. Dengan program DPU perekonomian masyarakat tidak mampu sedikit demi sedikit dapat diangkat prekonomiannya dengan jalan diberikan modal untuk usaha dan dibimbing dengan pola pendampingan

4. Meningkatkan kesejahteraan masyarakat dalam bidang agama, pendidikan, kesehatan,

5. Menjadikan masyarakat yang mandiri yang mampu mencukupi kebutuhan ekonomi keluarganya,

6. Mengubah pola hidup masyarakat miskin, berupaya mengubah kaum mustahik menjadi muzaki atau mreka yang sebelumnya menerima zakat menjadi pemberi zakat.

7. Menjadikan masyarakat yang berakhlak dan mengerti, serta menjalankan agama dengan baik dan benar.

Berdasarkan hasil penelitian dilapangan atau daerah yang menjadi program DPU-DT, yaitu Program Desa Ternak Mandiri maka perlu diperluas atau ditambah program-program pemberdayaan usaha masyarakat yang tidak mampu, dengan program pemberdayaan lainnya bukan hanya pemberdayaan ternak domba bakalan tetapi program yang lain misalkan kerajinan bambu pembuatan condre. Atau semakin banyak potesi lokal yang diberdayakan.

Program Desa Ternak Mandiri juga bisa diterapkan pada daerah perdesaan lainnya, agar peternak didaerah bisa menjadi peternak yang mandiri dan berakhlak baik sebagai tujuannya.[] 


\section{DAFTAR PUSTAKA}

Abul A'la al-Maududi, 1991. Terjemah,. Prinsip-Prinsip Islam, Bandung: Al-Ma'arif

Ahmad, Amrullah (Ed.). 1983. Dakwah Islam dan Perubahan Sosial. Yogyakarta: PLP2M.

Agus Ahmad Safei dan Nanih Machendrawati, 2003. Pengembangan masyarakat Islam Dari Ideologi, Strategi Sampai Tradisi, Bandung:Remaja Rosda Karya

Agus Shamdan, 2004. Indikator Potensi dan Sumber Kesejahteraan Sosial Ditinjau dari Aspek Ketahanan Sosial Masyarakat, Jakarta: Departemen Sosial RI

Aziz, Ali. 2009. Ilmu Dakwah. Jakarta: Kencana.

Departemen Agama. 1984. Al-Qur'an dan Terjemahnya.Jakarta.

Devito, Joseph A. 2001. The Interpersonal Communication Book. New York: Longman.

Esposito, John L. (Ed.). 1995. The Oxford Encyclopedia of the Modern Islamic World, Volume I. Oxford: Oxford University Press.

Edi Suharto, 2005. Membangun Masyarakat Memberdayakan Rakyat, Bandung: Refika Aditama,

Harry Hikmat, 2006. Strategi Pemberdayaan Masyarakat, Bandung: Humaniora

Kurzman, Charles (Ed.). 2002. Modernist Islam 1840-1940. Oxford: Oxford University Press.

Mulkhan, Abdul Munir. 1996. Ideologisasi Gerakan Dakwah. Yogyakarta: SI Press. 2002. Teologi Kiri. Yogyakarta: Kreasi Wacana.

M. Jafar Hafsah, Pengentasan Kemiskinan Melalui Pemberdayaan Masyarakat, (Bandung: Iris Press, 2006

Muhammad Sayyid Muhammad Yusuf, 2007. Al-tamkiin li al-ummati alIslamiyah, Al-Azhar: Dar al-Salam 
Poston, Larry. 1992. Islamic Da'wah in the West. New York: Oxford University Press.

Pranaka, A.M.W. dan Vidhyandika. 1996. Pemberdayaan: Konsep, Kebijakan dan Implementasi. Jakarta: CSIS.

Salim Bahreisy dan H. Said Bahreisy, 2005. Terjemah Singkat Tafsir Ibu Katsir, Surabaya: PT. Bina Ilmu

Vic George \& Paul Wilding,1992. Ideologi dan Kesejahteraan Rakyat, Jakarta: Grafiti

Yunus, Muhammad. 2007. Bank Kaum Miskin, Terj. Irfan Nasution. Serpong: Marjin Kiri. 